\title{
Trans-synaptic Regulation of NMDA Receptor RNAs during Optic Nerve Regeneration
}

\author{
Virginia C. Hieber and Daniel Goldman \\ Mental Health Research Institute and Department of Biological Chemistry, University of Michigan, Ann Arbor, \\ Michigan 48109
}

\begin{abstract}
A goldfish NMDA receptor (NMDAR) cDNA was used to analyze NMDAR RNA expression during optic nerve regeneration. Following crush of the optic nerve, NMDAR RNA levels initially decrease and then increase in retinal ganglion cells. This latter increase corresponds with the time when ganglion cell axons are forming stable connections with their targets in the optic tectum. NMDAR RNA stability assays indicate that the increase in this RNA is largely a result of increased NMDAR gene expression. This increase requires return of electrical activity in the regenerating axons, interaction between ganglion cell axons and their targets in the optic tectum, and functional NMDARs in the postsynaptic tectal cells. These requirements for induction of presynaptic NMDAR RNA are similar to those proposed for synapse stabilization during development and regeneration of the visual system and during long-term potentiation (LTP) in the hippocampus.
\end{abstract}

[Key words: goldfish retina, gene expression, synapse stabilization, retinal ganglion cell, activity-dependent regulation, visual map refinement]

Fish and amphibians possess a remarkable ability to regenerate damaged CNS neurons (Grafstein, 1986). Surprisingly little is known about the molecular mechanisms mediating this process. Characterization of these mechanisms will not only facilitate our understanding of CNS regeneration in lower vertebrates and perhaps suggest ways to induce it in mammals, but also shed light on mechanisms contributing to neurite outgrowth and synaptogenesis during development. In addition, the plasticity associated with regeneration makes it an attractive model to identify mechanisms that might contribute to synaptic remodelling.

Our approach to characterizing these mechanisms is to identify genes induced at different times of nerve regeneration and use these molecules as probes for mechanisms controlling their expression. We had previously identified two sets of genes that are induced at different times during optic nerve regeneration; genes encoding $\alpha$-tubulins are induced within $3 \mathrm{~d}$, while those encoding $\mathrm{nAChRs}$ are induced within $7 \mathrm{~d}$ following optic nerve

\footnotetext{
Received Aug. 19, 1994; revised Mar. 1, 1995; accepted Mar. 3, 1995.

We thank Dr. Koki Moriyoshi for providing the rat NMDARI cDNA clone, Diane Vista and Donny Huang for assistance with in situ hybridization assays, and Dr. Roger Davis for discussions and advice on goldfish injection procedures. We also thank Larry Adams for help with RNase protection assays. This work was supported by a grant from the Lucille P. Markey Charitable Trust to D.G.

Correspondence should be addressed to Daniel Goldman, University of Michigan, Mental Health Research Institute, 205 Zina Pitcher Place, Ann Arbor, MI 48109

Copyright (C) 1995 Society for Neuroscience $\quad 0270-6474 / 95 / 155286-11 \$ 05.00 / 0$
}

damage (Hieber et al., 1992). This temporal expression pattern corresponds with neurite outgrowth (tubulin) and the beginning of synaptogenesis $(\mathrm{n} \Lambda \mathrm{ChRs})$. Indeed, induction of $\mathrm{n} \Lambda \mathrm{ChR}$ gene expression requires interactions between the regenerating retinal ganglion cell axon and its brain target (Hieber et al., 1992). However, functional recovery of vision does not take place until 2-3 months postoptic nerve crush, implying events involved in forming functional synapses are still occurring after $\mathrm{nAChR}$ gene induction is observed. One such event is the refinement and stabilization of appropriate synaptic connections between retinal ganglion cell axons and their brain targets.

A candidate probe for these later events is the NMDA receptor (NMDAR). Recent studies indicate a role for the postsynaptic NMDAR in the establishment of normal connections in visual systems of lower vertebrates and mammals, as well as for synapse stabilization in regenerating systems (Constantine-Paton et al., 1990; Cline, 1991). In addition, functional NMDARs have been demonstrated in retinal ganglion cells of mammals, amphibians, and fish (Boos et al., 1990; Massey and Miller, 1990; Coleman and Miller, 1989; Gottesmann and Miller, 1992; Yazejian and Fain, 1992). Therefore, to develop a probe for events mediating synapse stabilization, we have isolated an NMDAR clone from a goldfish retinal cDNA library and studied its regulated expression during optic nerve regeneration.

Although we expected NMDAR regulation during optic nerve regeneration to be confined to the postsynaptic cells in the optic tectum, we were surprised to find a robust regulation of this gene in retinal ganglion cells. Following crush of the optic nerve, NMDAR RNA decreases and later increases in retinal ganglion cells. We have correlated the increase in NMDAR gene expression in the presynaptic ganglion cell with synapse stabilization in the tectum. This correlated expression is disrupted by multiple crushes of the optic nerve, tectal ablation, tetrodotoxin injection into the eye, or administration of NMDAR antagonists to the postsynaptic target. These results suggest that the increase in NMDAR gene expression in the retinal ganglion cell is regulated via a retrograde messenger derived from the tectum and generated in response to activation of tectal NMDARs.

\section{Materials and Methods}

Goldfish maintenance and surgery. Maintenance of goldfish, optic nerve crush, and tectal ablations were carried out as described previously (Hieber et al., 1992). Briefly, common goldfish (Carassius auratus) of $5-7 \mathrm{~cm}$ length were maintained at $25^{\circ} \mathrm{C}$ in well-aerated tanks. Right optic nerve crush was carried out just behind the orbit in tricaine methane sulfonate $(0.1 \%)$-anesthetized fish. The left optic nerve of each fish was left intact with the left retina serving as an unoperated control. Tectal ablations were carried out on anesthetized goldfish after cutting into the skull with a scapel and lifting a flap over the left optic tectum. 
The tectum was removed by aspiration and the skull flap gently placed back into position. Sham-operated fish underwent identical procedures but without optic nerve crush, and the retinas from these fish were used as additional controls. After surgery, fish were returned to their tanks until they were killed.

For experiments involving activity blockade in the ganglion cells, five microliters of a $10^{-5} \mathrm{M}$ TTX solution was injected into the vitreous humor of the right eye of fish using a 30 gauge needle attached to a Hamilton syringe. Injections were repeated every other day for a length of time determined by the experimental protocol. Control eyes received saline injections. The effectiveness of TTX blockade was measured using a behavioral assay (Davis and Schlumpf, 1984). For experiments of actinomycin D inhibition of messenger RNA synthesis, $0.25 \mu \mathrm{g}$ of actinomycin D in $5 \mu l$ of saline was injected into the vitreous humor of the right eye of goldfish. For experiments involving inhibition of axonal transport, $0.5 \mu \mathrm{g}$ of colchicine in $5 \mu \mathrm{l}$ of saline was injected as above. For experiments involving exposure of the tecta to drugs, a small hole was made in the skull of goldfish above the tectal surface of the brain using a 26 gauge needle. Ten microliters of either $4.4 \mathrm{~mm}$ MK801, 1 mM D,L-2-amino-5-phosphonovalerate (APV) or $1 \mathrm{mM}$ L-APV was delivered daily for a 1-2 week period through this opening using a 30 gauge needle attached to a Hamilton syringe. The fluid space around the brain was estimated to be 50 to $100 \mu \mathrm{l}$ in these fish producing a 5to 10 -fold dilution of the injected drugs. This concentration of D,LAPV is similar to that which has been used to block tectal NMDARs in amphibian systems (Scherer and Udin, 1989; Hickmott and Constantine-Paton, 1993). To test the effect of intraocular administration of these drugs, $5 \mu \mathrm{l}$ of the same concentrations was injected daily for a similar time period into the vitreous humor of the right eye of goldfish. Eye volume was estimated to be 25 to $50 \mu$ in these fish producing a 5- to 10-fold dilution of drugs injected intraocularly.

Isolation and characterization of $c D N A$ clones. An amplified goldfish retinal cDNA library was screened using a radiolabeled rat NMDAR1 cDNA (Moriyoshi et al., 1991) as a probe. Positive-reacting clones were purified to homogeneity, and the isolated cDNAs compared by restriction mapping. EcoR1 digestion was used to release the inserts from these clones that were subcloned into the Bluescript SK $(-)$ vector (Stratagene) for DNA sequencing. Unidirectional deletions were generated in the cDNA insert using Exonuclease III as described before (Hieber and Goldman, 1993). Double-stranded DNA was sequenced using Taq polymerase and thermal cycling with the Applied Biosystems automated DNA sequencer.

RNase protection experiments. Total cellular RNA was isolated from goldfish retinas using a modification of the guanidine thiocyanate method (Hieber and Goldman, 1993). A 529 base pair (bp) RNA probe encompassing the entire $3^{\prime}$ untranslated region and 105 base pairs of translated sequence preceding the termination codon, was generated by run-off transcription of linearized vector in the presence of ${ }^{32} \mathrm{P}$-UTP. The RNase protection assay was performed as previously described (Goldman and Staple, 1989). The RNA probe was hybridized with 20 $\mu g$ of RNA overnight at $55^{\circ} \mathrm{C}$, digested with RNase A for $1 \mathrm{hr}$, and the products were analyzed on a denaturing polyacrylamide gel. Probe integrity was confirmed by omitting RNase from the procedure. After drying, gels were exposed to $\mathrm{x}$-ray film with an intensifying screen at $-80^{\circ} \mathrm{C}$.

In situ hybridization and data analysis. Fish were dark adapted and retinas removed and processed for in situ hybridization as previously described (Hieber et al., 1992). ${ }^{35}$ S-Labeled sense and antisense RNA probes were prepared from linearized vectors containing the entire goldfish NMDAR cDNA insert, $\alpha-3$ nicotinic acetylcholine receptor (nAChR) (Hieber et al., 1990), or $\alpha$-tubulin (Hieber et al., 1992) cDNA inserts. Tissue preparation, hybridization, and posthybridization conditions were as described previously (Hieber et al., 1992). Briefly, retinas were fixed in ice-cold $4 \%$ paraformaldehyde in phosphate-buffered sa-

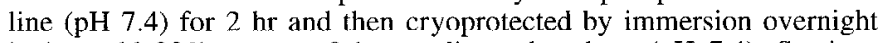
in ice-cold $30 \%$ sucrose $-0.1 \mathrm{M}$ sodium phosphate $(\mathrm{pH}$ 7.4). Sections $(15 \mu \mathrm{l})$ were cut on a cryostat and mounted on poly-l-lysine-coated slides. Prior to in situ hybridization, sections were digested with pro teinase $\mathrm{K}(10 \mu \mathrm{g} / \mathrm{ml})$ for $5 \mathrm{~min}$ at $37^{\circ} \mathrm{C}$ and acetylated with acetic anhydride. Sections were covered with hybridization buffer containing $5 \times 10^{4} \mathrm{cpm} / \mu \mathrm{l}$ of radiolabeled-RNA probe and incubated at $55^{\circ} \mathrm{C}$ for 21 hr. Posthybridization treatments included digestion with RNase A $(50 \mu \mathrm{g} / \mathrm{ml})$ for $30 \mathrm{~min}$ at $37^{\circ} \mathrm{C}$ and a wash in $0.5 \times$ saline-sodium citrate at $55^{\circ} \mathrm{C}$ for $60 \mathrm{~min}$. Following dehydration, slides were dipped in Kodak NTB-2 emulsion and exposed at $4^{\circ} \mathrm{C}$ for $1-4$ d. Exposure times were chosen such that the developed grains fell within the linear range of the emulsion. This linear range was determined by exposing slides with a constant amount of radiation for various lengths of time and counting grains.

After development, sections were examined and photographed with dark field optics using a Zeiss Axiophot microscope. Quantitation of RNA levels in these sections was performed by counting silver grains over 25-50 ganglion cells per retina. Ganglion cells were identified in the ganglion cell layer by their cytological appearance. Glia and vascular cells were not counted. Displaced amacrine cells represent a very small percent $(<1 \%)$ of the neurons in this layer (Hitchcock and Easter, 1986; Bloomfield and Hitchcock, 1991). Cells were randomly chosen for this analysis and included cells that contained background grain levels. The ratio of the total grains in ganglion cells of experimental retina to those in ganglion cells of control retina was calculated for each fish. These values were averaged for each time point (at least three tish) and reported as relative RNA level. Error bars are the standard error of the mean. Levels of significance $(p)$ were calculated using the two-tailed $t$ test.

\section{Results}

\section{NMDAR clone isolation and analysis}

To obtain a probe for studies of regulation of NMDAR gene expression during regeneration, a goldfish retinal cDNA library was screened with a rat NMDAR 1 (Moriyoshi et a1., 1991) probe. Several hybridization-positive isolates were characterized. Restriction enzyme analysis and Southern blot hybridization showed one clone of approximately $1.1 \mathrm{~kb}$ to predominate among the isolates. A sequence comparison with the rat NMDAR1 clone revealed that the goldfish clone contains a partial copy of the NMDAR RNA beginning in the cytoplasmic domain with an open reading frame of $608 \mathrm{bp}$ followed by a termination codon and 427 bp of $3^{\prime}$ untranslated sequence (Fig. 1). A further comparison of the translated amino acid sequence of the goldfish clone with those of the rat NMDAR 1 isoforms indicates the clone to most probably be the homologue of rat NMDAR1-4a or NMDAR1-4b of Hollmann et al. (1993) or R1E or R1G using the terminology of Sugihara et al. (1992). Although the goldfish sequence diverges from that of the rat isoforms at the nucleotide level, there is strong conservation at the protein level. A comparison with the rat R1E sequence identifies five amino acid differences (Fig. 1); the first two reside in the putative cytoplasmic domain, while the remaining three reside in the $3^{\prime}$ terminal coding region.

\section{Mulliple NMDAR isoform expression in goldfish retina}

RNase protection experiments were used to confirm that NMDAR RNA is represented in the retina. A radiolabeled antisense RNA probe spanning the $3^{\prime}$ terminal 529 nucleotides of the goldfish NMDAR cDNA was hybridized with total RNA isolated from normal goldfish retina. The presence of one protected band the size of the input probe minus plasmid sequences (529 bp, Fig. 2, band 1) together with several smaller bands among the protected species suggests that more than one type of retinal RNA with sequence identity to portions of the NMDAR probe exists in the retina. The band hybridizing most strongly to the probe at $105 \mathrm{bp}$ (Fig. 2, band 3) corresponds in size to the NMDAR protein coding region. A second strongly hybridizing band of 424 bp (Fig. 2, band 2) corresponds in size to the $3^{\prime}$ untranslated region of the probe. The other protected fragments probably represent alternatively spliced transcripts derived from the goldfish NMDAR1 gene. Control hybridization to tRNA showed no protected bands (data not shown). These results indicate that multiple isoforms of NMDAR1 are expressed in goldfish retina. 


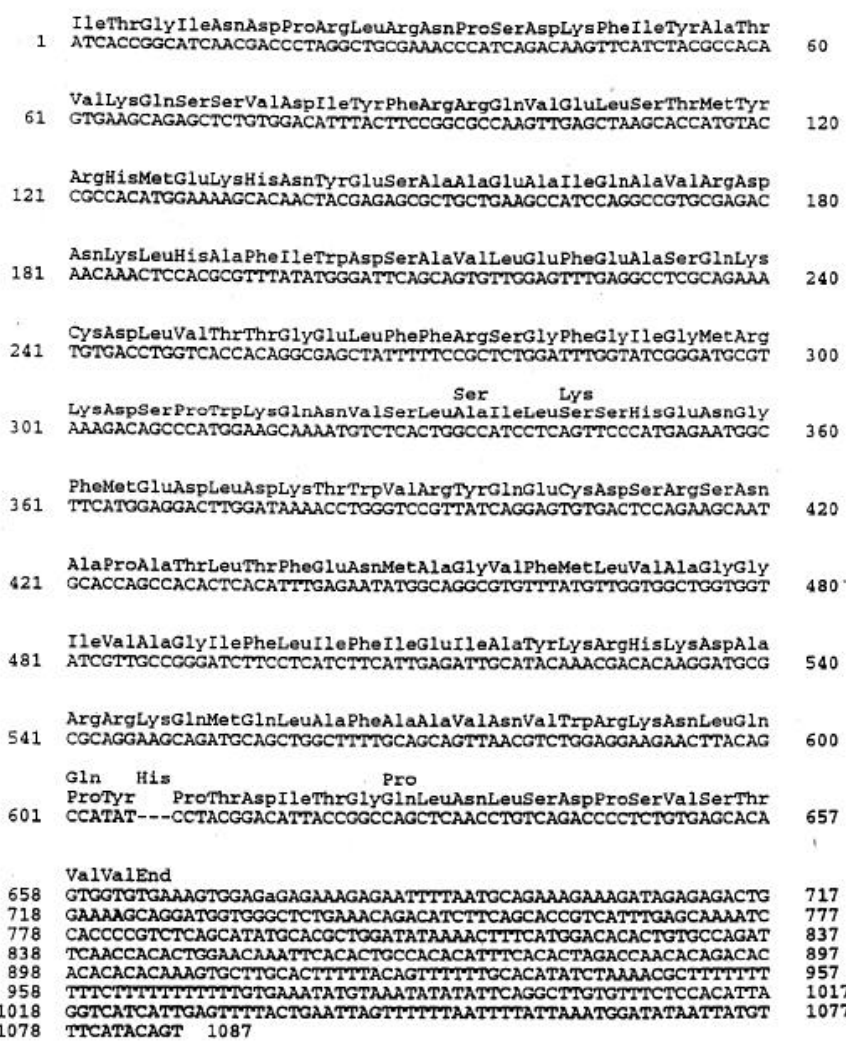

Figure 1. Partial nucleotide and deduced amino acid sequences of goldfish NMDAR cDNA. The goldfish clone begins at nucleotide 1990 of the rat NMDAR sequence (Moriyoshi et al., 1991). Amino acids that differ between rat and goldfish are indicated above the goldfish sequence.

\section{Location of NMDAR gene expression in goldfish retina}

NMDAR RNA was assayed by in situ hybridization in normal and regenerating goldfish retinal ganglion cells with an ${ }^{35} \mathrm{~S}-\mathrm{la}-$ beled RNA probe prepared from the goldfish NMDAR cDNA that detects all known splice variants. Levels for $\alpha$-tubulin and $\alpha-3$ nAChR RNAs were assayed in the same retina for comparison since in previous studies of regeneration these RNAs have demonstrated distinctive patterns of expression (Hieber et al., 1992). NMDAR RNA is abundantly expressed in the inner nuclear layer (INL) and, to a lesser extent, in the ganglion cell layer (GCL) of normal goldfish retina (Fig. 3A, control). This result is consistent with the experimental evidence that glutamate is a primary transmitter of information across the retina and that NMDA receptors are represented in the retina (Boos et al., 1990; Massey and Miller, 1990; Coleman and Miller, 1989; Gottesmann and Miller, 1992; Yazejian and Fain, 1992). This pattern differs from that of $\alpha$-tubulin and $\alpha-3 \mathrm{nAChR}$, both of which are more abundant in the GCL than in the INL.

\section{NMDAR RNA levels during regeneration}

Previous studies of $\alpha$-tubulin and nAChR RNAs in retina during optic nerve regeneration have shown characteristic changes in RNA levels, specifically in ganglion cells, despite the fact that these RNAs are expressed throughout the retina. Similarly, while NMDAR RNA is expressed most abundantly in the INL, the changes observed during optic nerve regeneration occur only in the ganglion cell layer.

NMDAR RNA levels begin to drop in ganglion cells of the

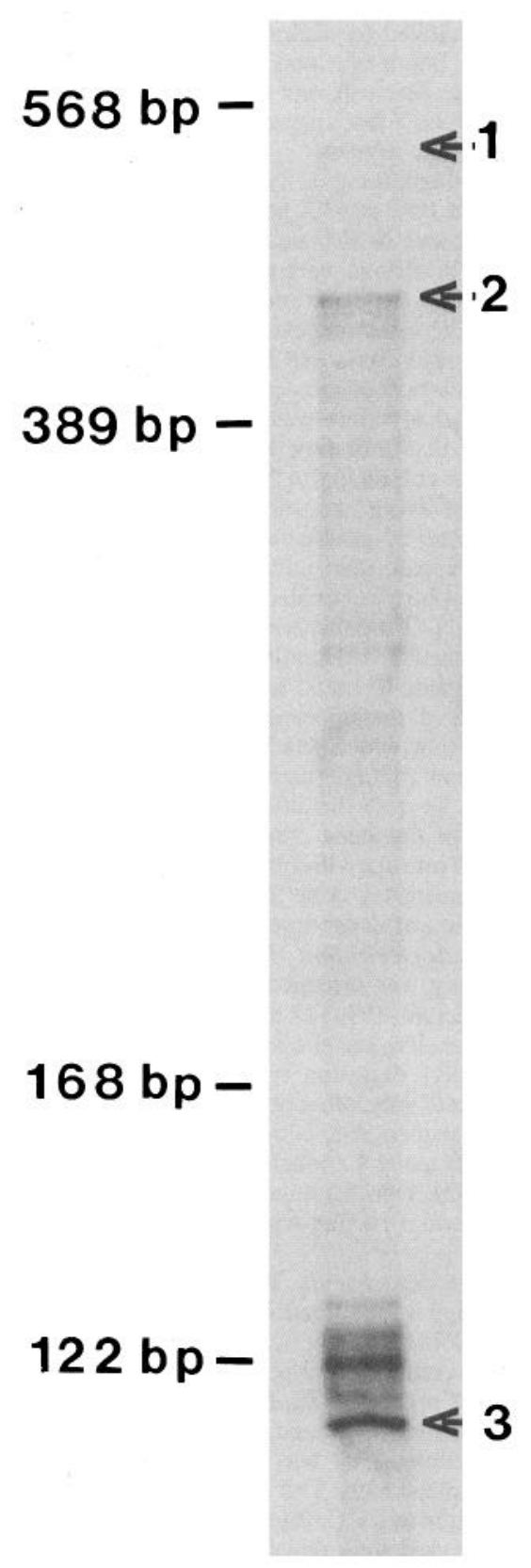

Figure 2. Multiple NMDAR RNA isoforms are expressed in the goldfish retina. RNase protection experiment with goldfish NMDAR cRNA probe spanning nucleotides 558-1087 and retinal RNA. Positions of size standards are shown on the left. Arrows indicate protected bands corresponding to sizes of input probe $(I), 3^{\prime}$ untranslated region (2), and protein coding region (3) of the NMDAR cDNA.

right retina $2 \mathrm{~d}$ following a crush of the right optic nerve (Fig. 3 ). The relative RNA level reaches a minimum of approximately $40 \%$ of the control (day 0$)$ value $(p<0.01)$ at day 3 postcrush. This lower level is maintained until day 10 , after which a slow rise begins followed by a more rapid rise from day 17 to day 20 and continues to reach a peak level at approximately $70 \%$ above the control value. This level of expression is maintained for at least $15 \mathrm{~d}$. By day 35 the increase above the control is 1.7 -fold $(p<0.01)$. A return to the control level is seen between 40 and $45 \mathrm{~d}$ postcrush.

In contrast (as reported previously, Hieber et al., 1992), $\alpha$-tu- 
A

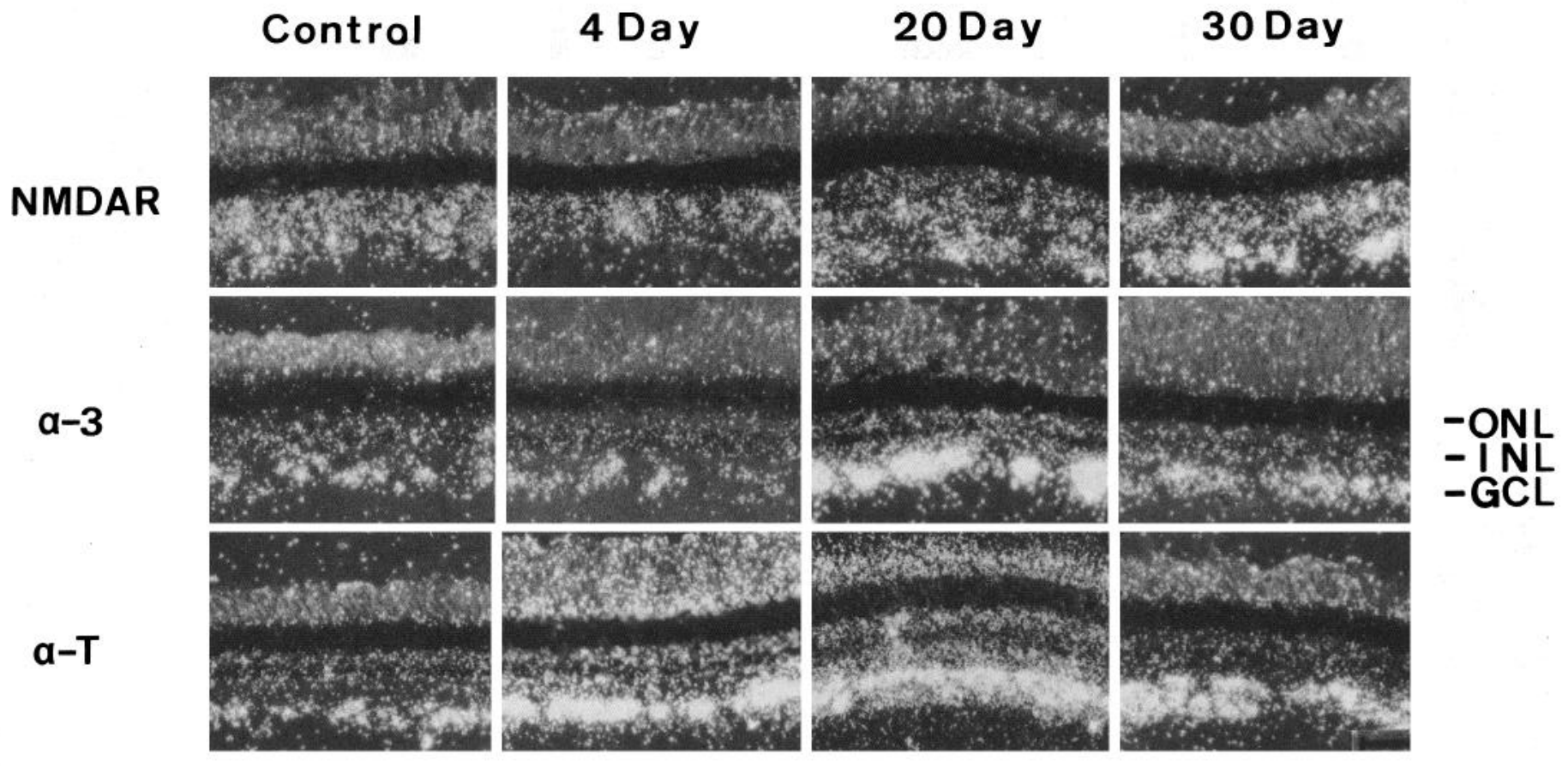

B

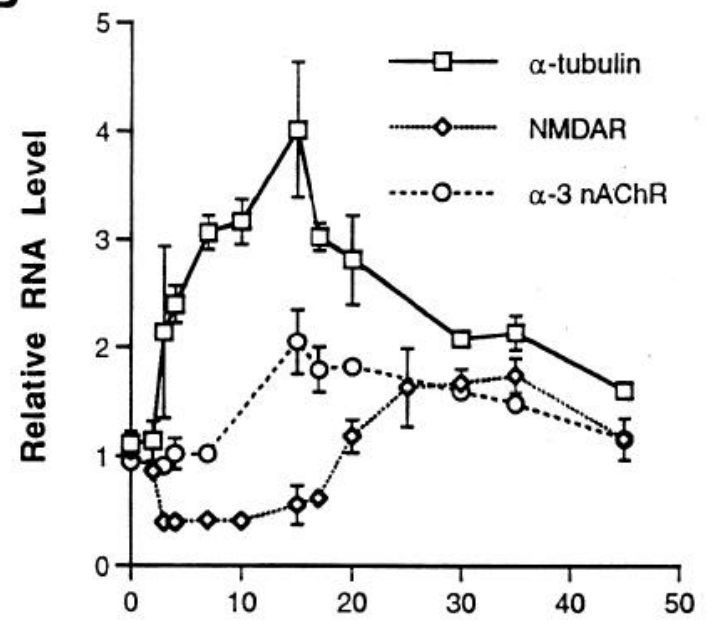

Days Postcrush

Figure 3. Time course of expression of retinal NMDAR, $\alpha-3 \mathrm{nAChR}$, and $\alpha$-tubulin RNAs during optic nerve regeneration. The right optic nerve was crushed on day 0 . Right and left retinas were removed at various times postcrush and processed for in situ hybridizations. A, In situ hybridization profiles of NMDAR, $\alpha-3 \mathrm{nAChR}$, and $\alpha$-tubulin RNAs during optic nerve regeneration. Left retinas, which served as nonregenerating controls, showed no detectable changes in RNA levels over the time course of the experiment. The column labeled control corresponds to left retina of experimental fish. Photomicrographs were taken with a 20× objective lens using dark-field optics. Abbreviations: $\alpha-3$, nAChR $\alpha-3$ subunit; $\alpha-T$, $\alpha$-tubulin; $O N L$, outer nuclear layer; $I N L$, inner nuclear layer; $G C L$, ganglion cell layer. Scale bar, $100 \mu \mathrm{m}$. $B$, Quantitation of changes in retinal ganglion cell RNAs as a function of time after optic nerve crush. Left (control) and right (optic nerve crushed) retinas were removed from fish at various times following optic nerve crush and processed for in situ hybridization. After the slides were developed, grains over ganglion cells were counted. Values (relative RNA level) are reported as the ratio of grains in regenerating ganglion cells to grains in control ganglion cells (see Materials and Methods). Each value represents the average from three individual fish. Error bars are SEM. 


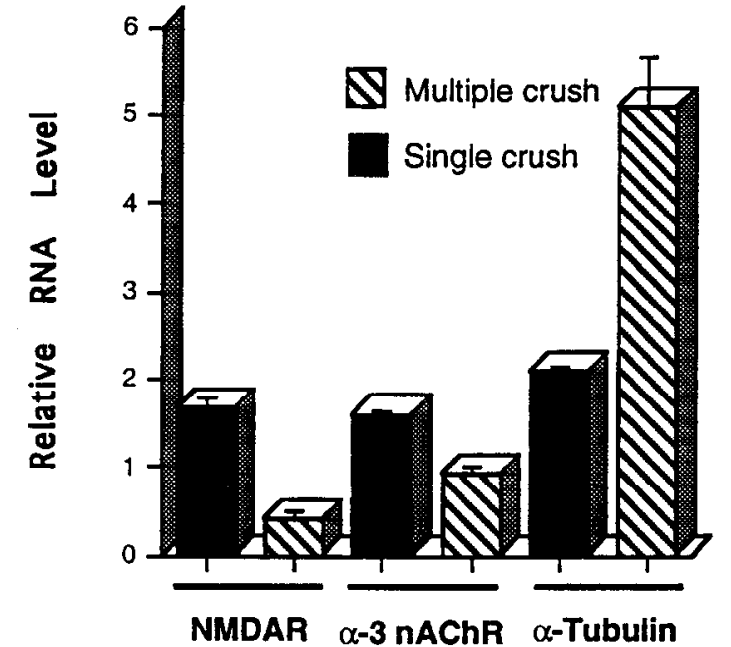

Figure 4. Target-dependent regulation of retinal ganglion cell NMDAR, $\alpha-3$ nAChR, and $\alpha$-tubulin RNAs. The right optic nerve of fish was either crushed once or repeatedly at $5 \mathrm{~d}$ intervals over a period of $28 \mathrm{~d}$. At $28 \mathrm{~d}$ the right and left retinas were removed and processed for in situ hybridization, and the relative levels of NMDAR, $\alpha-3$ $\mathrm{nAChR}$, and $\alpha$-tubulin RNAs were determined. Relative RNA levels are reported as the ratio of grains in regenerating ganglion cells (right retina) to grains in control ganglion cells (left retina). Values indicate the means \pm SEM for four goldfish.

bulin RNA levels in ganglion cells of the right retina begin to rise by day 3 postcrush, reach a maximum level at day 15 , then decline to precrush levels over a 2-3 month period. The ganglion cell $\alpha-3 \mathrm{nAChR}$ RNA level in the right retina rises after day 10 postcrush to a maximum value around day 15 and then, as for $\alpha$-tubulin, declines to precrush levels over the following $2-3$ months.

\section{Effects of actinomycin D on NMDAR RNA levels during regeneration}

The changes in NMDAR RNA levels that occur in retinal ganglion cells around days 3 and 28 postcrush might be the result of an altered turnover of the RNA and/or a change in RNA synthesis. We were unsuccessful in assaying NMDAR gene transcription by nuclear run-on assays. Therefore, we assayed NMDAR RNA stability at various times during optic nerve regeneration. Actinomycin D was injected into the right eye of goldfish at a concentration shown in preliminary studies to block messenger RNA transcription in retinal ganglion cells by over 95\% during a $24 \mathrm{hr}$ period. NMDAR RNA levels were then quantitated in right and left retinal ganglion cells at 0 and $24 \mathrm{hr}$ following injection. This analysis was performed on normal control fish and those whose optic nerves were crushed. Changes in RNA levels were assayed on days 2 and 3 postcrush, when NMDAR RNA levels are decreasing, and days 27 and 28, when NMDAR RNA levels are increasing.

In the presence of actinomycin, we found approximately $40 \%$ less NMDAR RNA on day 3 comparcd to day 2 postcrush. However, blocking transcription in normal control retina only resulted in a $15 \%$ drop in this RNA over the same time period. This suggests that the decrease in NMDAR RNA occurring during the first few days following optic nerve crush is, at least in part, due to increased NMDAR RNA turnover. In contrast, if this same analysis is done on days $27-28$ postcrush, when NMDAR RNA is increasing, we found that in the presence of actinomycin there is approximately $26 \%$ less NMDAR RNA on day 28 com-

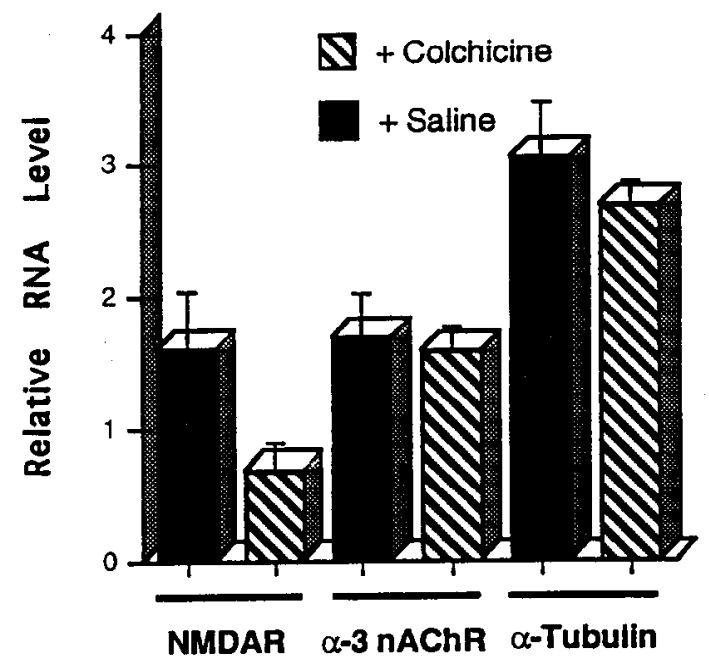

Figure 5. Intraocular injection of colchicine blocks the increase in retinal ganglion cell NMDAR RNA levels normally occurring at 18-27 d postcrush. Goldfish were given a single $5 \mu$ intraocular injection of saline (control) or of colchicine $(0.5 \mu \mathrm{g})$ at $18 \mathrm{~d}$ postcrush. Retinas were removed for in situ hybridization assays at $27 \mathrm{~d}$ postcrush, and the relative levels NMDAR, $\alpha-3 \mathrm{nAChR}$, and $\alpha$-tubulin RNAs were determined. Relative RNA levels are reported as the ratio of grains in regenerating ganglion cells (right retina) to grains in control ganglion cells (left retina). Values represent the means \pm SEM for four goldfish.

pared to day 27. Since this rate of turnover is higher than in the control retina (approximately $15 \%$ drop over $24 \mathrm{hr}$ ) and because NMDAR RNA is increasing by $30 \%$ during this same time period, it appears that increased NMDAR gene transcription largely accounts for the changes in its RNA during this time period.

\section{Effects of tectal contact on NMDAR RNA levels}

Since the rise in NMDAR RNA level occurs at a time when the regenerating axons from the ganglion cells are interacting with the tectum (Bernhardt, 1989), we tested whether this interaction was required for NMDAR RNA induction. Retinal ganglion cell axons were prevented from contacting the tectum by repeated crushes (every $5 \mathrm{~d}$ ) over a $28 \mathrm{~d}$ period. Under these conditions, NMDAR RNA levels in ganglion cells of the right retina do not increase but rather remain at the lower level seen at day 4 (Fig. 4). As observed previously, multiple crushes of the regenerating optic nerve blocks the rise in $\alpha-3 \mathrm{nAChR}$ and the decrease in $\alpha$-tubulin RNA levels that normally take place during optic nerve regeneration (Fig. 4). When innervation of the tectum by the regenerating axons was prevented by tectal ablation, NMDAR RNA levels in ganglion cells of the right retina did not show the increase at day 20 postcrush that would otherwise have been seen (relative RNA level of $0.44 \pm 0.06$ for nerve crush/tectum ablated fish as compared with $1.19 \pm 0.15$ for nerve crush fish without tectal ablation), again indicating that tectal contact is necessary for this increase to occur. As in the case of multiple crushes, the rise in $\alpha-3$ nAChR RNA level was blocked by tectal ablation (relative RNA level of $0.98 \pm 0.06$ for nerve crush/tectum ablated fish as compared with $1.76 \pm$ 0.08 for control nerve crush fish) and the decrease in $\alpha$-tubulin RNA level that normally takes place by this time did not occur (relative RNA level of $5.65 \pm 0.35$ for nerve crush/tectum ablated fish as compared to $2.75 \pm 0.28$ for nerve crush fish). 


\section{Effects of colchicine on NMDAR RNA levels}

The administration of appropriate doses of intraocular colchicine have been shown to reversibly inhibit axonal transport for up to 2 weeks (Davis et al., 1990). Although the retinotectal projection has been shown to continue to mediate visual responses following an intraocular injection of 0.1 or $0.5 \mu \mathrm{g}$ of colchicine, such a dose reversibly inhibits regeneration of retinal afferents following optic nerve crush and may inhibit the arrival of new retinal afferents in the tectum (Davis et al., 1985, 1990). Therefore, injection was performed at $18 \mathrm{~d}$ postcrush, a time by which the maximum number of regenerating axons have entered the tectum and begun to form synapses (Springer and Agranoff, 1977; Stuermer and Easter, 1984). Colchicine injection under these conditions, while having no significant effect on $\alpha$-tubulin or $\alpha-3$ nAChR RNA levels, does produce a significant reduction in NMDAR RNA level $(p<0.05)$ measured $9 \mathrm{~d}$ after injection as shown in Figure 5. Colchicine injection into the right eye of control fish produces no significant change in NMDAR RNA level after a similar time interval.

\section{Effects of electrical activity on NMDAR RNA levels}

Lesion of the goldfish optic nerve results in a suppression of electrical activity (Northmore, 1987). Following axotomy, a rapid decrease in impulse activity occurs between 2 and $4 \mathrm{~d}$, reaches a minimum between 10 and $14 \mathrm{~d}$, and then gradually returns to normal. We, therefore, tested whether a suppression of electrical activity would affect NMDAR RNA levels in retinal ganglion cells. For this experiment TTX was injected into the vitreous humor of the right eye of normal goldfish every other day for up to 2 weeks to block ganglion cell impulse activity. Control eyes received saline injections. No significant differences were found in NMDAR RNA levels in the control and I'IX-injected retinas (data not shown). Levels of $\alpha$-tubulin and nAChR RNAs also remaincd unchanged as reported previously (Hicber ct al., 1992). Thus, we conclude that changes in electrical activity alone are not responsible for the drop in ganglion cell NMDAR RNA level observed following optic nerve crush.

Intraocular injection of TTX into the goldfish eye following optic nerve crush, while without effects on initial outgrowth of the optic nerve and synapse formation in the tectum, has been reported to inhibit refinement of the relinotopic map (Meyer, 1983; Schmidt and Edwards, 1983). These previous investigations suggest that returning optic nerve activity following synapse formation plays a role in refinement of the synaptic connections during regeneration. We, therefore, tested whether TTX injections following optic nerve crush, at a time when electrical

Figure 6. Intraocular injection of TTX specifically blocks the rise in NMDAR RNA levels normally occurring after day 10 of regeneration. At various times following optic nerve crush, TTX or saline was injected into the eye every other day for a 7-13 day period, after which retinas were removed for in situ hybridization assays of NMDAR, $\alpha-3$ nAChR, and $\alpha$-tubulin RNAs. Relative RNA levels are reported as the ratio of grains in regenerating ganglion cells (right retina) to grains in control ganglion cells (left retina). $A$, The right optic nerve was crushed on day 0. TTX injections were administered intraocularly in the right eye starting at day 7 postcrush and repeated every $2 \mathrm{~d}$ until the time of sacrifice at day 14 . The values represent the means \pm SEM for four goldfish. $B$, TTX injections were started at day 10 postcrush and repeated every 2 d until sacrifice at day 21 . The values represent the means \pm SEM for five goldfish. $C$, TTX injections were started at day 20 postcrush and repeated every other day until sacrifice at day 33 . The values represent the means \pm SEM for four goldfish.
A
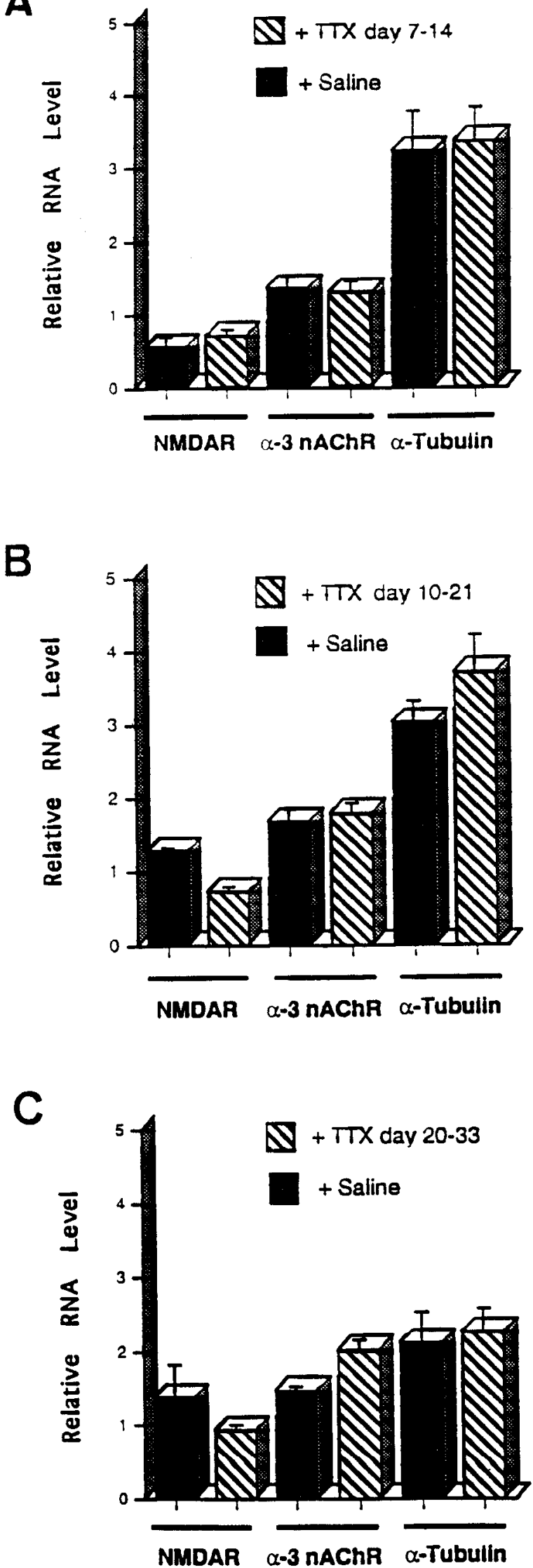


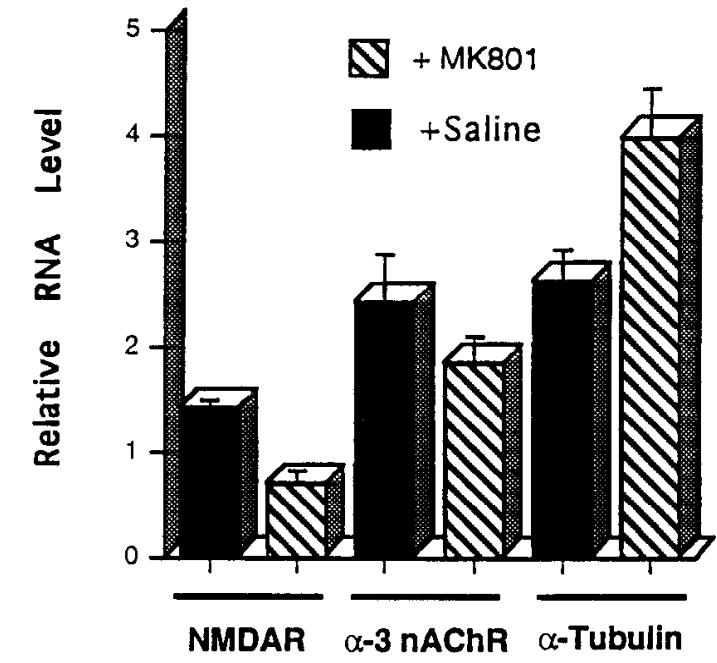

Figure 7. MK801 applied to the tectum blocks the increase in presynaptic ganglion cell NMDAR RNA normally occurring at $17-25 \mathrm{~d}$ postcrush. Goldfish were given daily intracranial injections $(10 \mu \mathrm{l})$ of either MK801 (4.4 mM solution) or saline (control) beginning on day 17 and ending on day 25 postcrush. Retinas were then removed for in situ hybridization assays, and the relative levels of NMDAR, $\alpha-3$ $\mathrm{nAChR}$, and $\alpha$ - tubulin RNAs were determined. Relative RNA levels are reported as the ratio of grains in regenerating ganglion cells (right retina) to grains in control ganglion cclls (Icft rctina). Values represent the means \pm SEM for four goldfish.

activity was returning in the optic nerve, would have an effect on the rise in NMDAR RNA levels seen between 10-30 d after optic nerve crush.

When TTX injections were begun in the right eye at day 7 postcrush and repeated every other day for a week, no significant difference was seen in levels of RNA for NMDAR, $\alpha-3$ nAChR, or $\alpha$-tubulin in ganglion cells of the right relative to the left retina as compared with control uninjected day 14 postcrush goldfish (Fig. 6A). When TTX injections were begun in the right eye at day 10 postcrush and continued to day 21 , the relative NMDAR RNA level was significantly less than that seen in the right relative to the left retina of control uninjected day 21 postcrush goldfish $(p<0.01)$ (Fig. $6 B)$. The relative RNA levels for $\alpha-3 \mathrm{nAChR}$ and $\alpha$-tubulin were not significantly different in the two groups of animals. When TTX injections were begun at day 20 postcrush, the relative RNA level for NMDAR in retinal ganglion cells of injected fish at day 33 postcrush was significantly lower than that of uninjected postcrush fish $(p<$ 0.01 ) (Fig. 6C). Although the relative RNA level was not significantly different for $\alpha$-tubulin in the injected as compared with the uninjected goldfish, a significant difference was found for $\alpha-3$ nAChR RNA $(p<0.01)$. Injection of TTX, starting at day 30 , consistently caused a slight but not statistically significant drop in the NMDAR RNA level in retinal ganglion cells of the injected fish analyzed at day 35 postcrush without affect- ing relative levels of $\alpha-3 \mathrm{nAChR}$ or $\alpha$-tubulin RNAs (data not shown).

\section{Effects of NMDAR antagonists on NMDAR RNA levels}

The rise in retinal ganglion cell NMDAR RNA can be prevented either by blocking electrical activity in the retina with TTX, by eliminating contact between regenerating ganglion cell axons and tectal cells, or by blocking retrograde transport in retinal ganglion cells via colchicine injection into the eye. The effectiveness of the latter two treatments suggests that interaction and axonal transport between tectum and retina may be necessary for the rise in ganglion cell NMDAR RNA levels at this period of regeneration. Since infusion of NMDAR antagonists into the tectum has been shown to produce effects on the retinotectal map that are similar to those produced by intraocular TTX injection (Schmidt, 1990), we tested whether application of these antagonists to the tectum at this stage of regeneration would have an effect on ganglion cell NMDAR RNA levels. NMDAR antagonists were infused into the cranial cavity during the period of activity-dependent synaptic rearrangements and the effects on retinal ganglion cell RNA levels were determined. In these experiments, goldfish, at various times following crush, received daily injections of either a specific drug or the vehicle alone above the tectal area.

As can be seen in Figure 7, injection of the noncompetitive NMDAR antagonist MK801 from 17 to $25 \mathrm{~d}$ postcrush prevents the rise in retinal ganglion cell NMDAR RNA $(p<0.05$ as compared with control fish), which would otherwise be seen during this time. Under these conditions, the level of $\alpha$-tubulin RNA does not fall as compared with saline-injected control fish $(p<0.05$ ), while that of $\alpha-3$ nAChR RNA does not differ significantly from control fish $(p>0.05)$. When goldfish were injected with the competitive NMDAR antagonist D,L-APV from 19 to $32 \mathrm{~d}$ postcrush (Fig. 8), the rise in retinal ganglion cell NMDAR RNA again is prevented ( $p<0.05$ ), while injection of the less active enantiomer, L-APV, has no significant effect on NMDAR RNA level. Fish injected with either L- or D,L-APV have significantly higher levels of $\alpha$-tubulin RNA ( $p$ $<0.01$ and $p<0.05$, respectively), while $\alpha-3$ nAChR RNA levels are again unaffected $(p>0.05)$. Injection of CNQX $(10$ $\mu \mathrm{l}$ of a $1 \mathrm{mM}$ solution), a non-NMDA glutamate receptor antagonist, is without significant effect on any of the three RNAs studied (data not shown).

To test whether blockade of retinal NMDARs by these antagonists was also able to prevent the rise in ganglion cell NMDAR RNA levels, the same concentrations of the antagonists were injected into the right eye of goldfish during a similar time period following optic nerve crush. In this case, no significant effects on relative levels of any of the three RNAs were found (Table I). Injections into the right eye of nonregenerating control fish for the same period of time also produced no significant change in the three RNA levels (data not shown).

Figure 8. D, L-APV applied to the tectum specifically blocks the increase in presynaptic ganglion cell NMDAR RNA normally occurring at 19$32 \mathrm{~d}$ postcrush. Goldfish were given daily intracranial injections $(10 \mu \mathrm{l})$ of saline (control), L-APV (1 mM), or D,L-APV ( 1 mM) beginning on day 19 and ending on day 32 postcrush. Retinas were then removed for in situ hybridization assays, and the relative levels of NMDAR, $\alpha-3$ nAChR, and $\alpha$-tubulin RNAs were determined. $A$, In situ hybridization profiles of NMDAR, $\alpha-3 \mathrm{nAChR}$, and $\alpha$-tubulin RNAs in right retinas of salineinjected (control) and D,L-APV-injected $(+\mathrm{D}, \mathrm{L}-\mathrm{APV})$ goldfish. Photomicrographs were taken with a $20 \times$ objective lens using dark-field optics. $O N L$, outer nuclear layer; $I N L$, inner nuclear layer; $G C L$, ganglion cell layer. $B$, Relative RNA levels for NMDAR, $\alpha-3 \mathrm{nAChR}$, and $\alpha$-tubulin RNAs in retinas of saline-injected, I-APV-injected and D,L-APV-injected goldfish. Relative RNA levels are reported as the ratio of grains in regenerating ganglion cells (right retina) to grains in control ganglion cells (left retina). Values represent the means \pm SEM for four goldfish. 
A

NMDAR

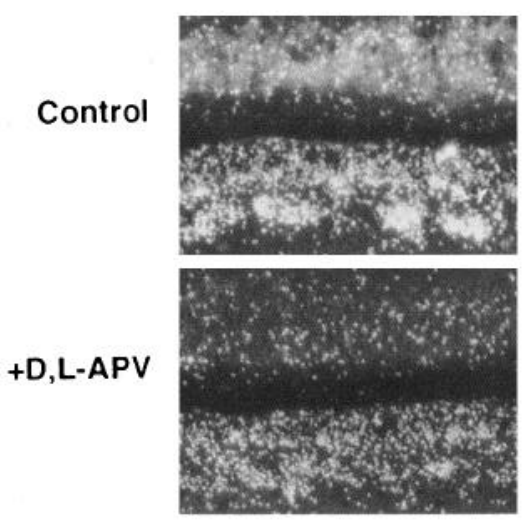

$(x-3$ nAChR

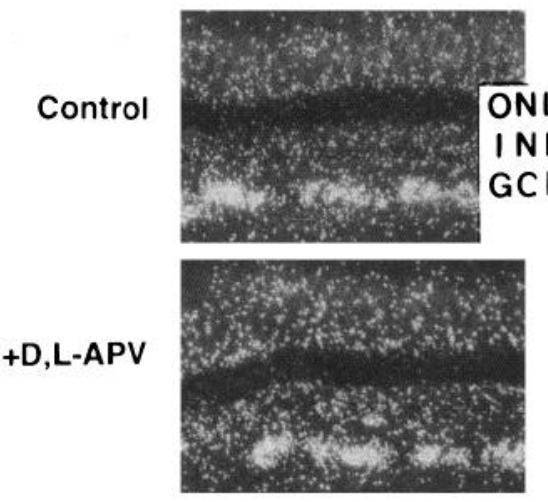

(x-Tubulin

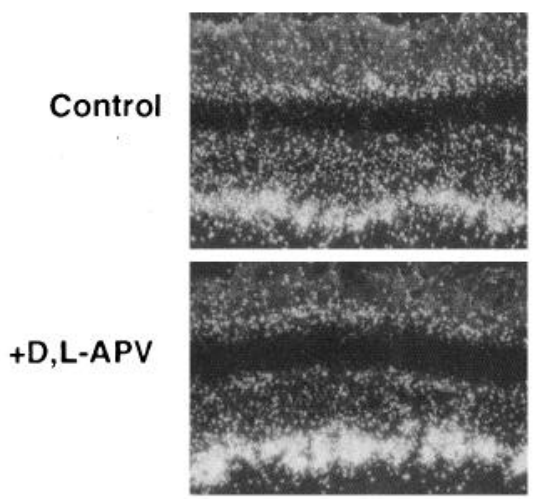

B
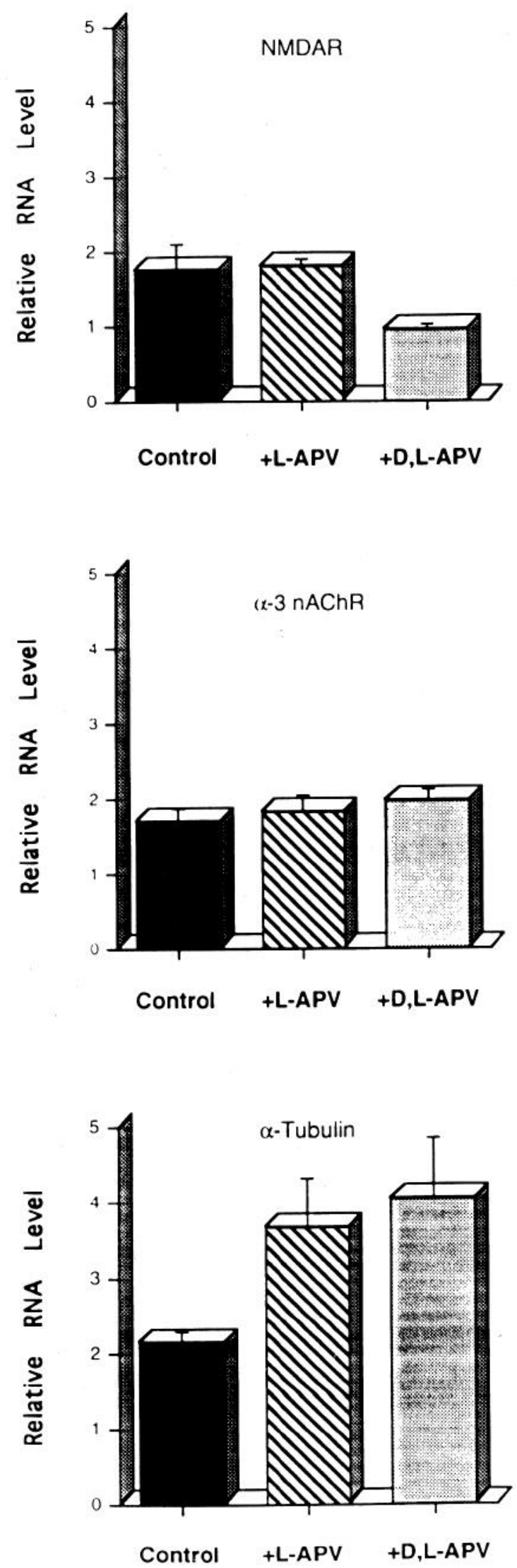
Table 1. Effects of intraocular drug administration on relative RNA levels in retinal ganglion cells

\begin{tabular}{llll} 
RNA & Saline & + MK801 & +D,L-APV \\
\hline NMDAR & $1.77 \pm 0.26$ & $1.65 \pm 0.12$ & $1.71 \pm 0.14$ \\
$\alpha-3 \mathrm{n} \Lambda$ ChR & $1.56 \pm 0.13$ & $1.44 \pm 0.15$ & $1.62 \pm 0.09$ \\
$\alpha$-Tubulin & $2.22 \pm 0.25$ & $2.54 \pm 0.49$ & $1.87 \pm 0.16$ \\
\hline
\end{tabular}

Goldfish were given daily intraocular injections $(5 \mu$ ) of saline (no drug), MK801 (4.4 mM solution), or D,L-APV (1 mM solution) beginning on day 17 and ending on day 32 postcrush. Retinas were them removed for in situ hy bridization assays and the relative levels of NMDAR, $\alpha-3$ nAChR, and $\alpha$-tubulin RNAs were determined. Relative RNA levels are reported as the ratio of grains in regenerating cells (right retina) to grains in control ganglion cells (left retina). Values represent the means + SF for five goldfish.

\section{Discussion}

The widespread expression of the NMDARs in the CNS and their participation in processes related to learning, memory, and other activity-dependent events is well established (Collingridge and Bliss, 1987; Constantine-Paton et al., 1990). Although the properties of the postsynaptic NMDARs in relation to these processes are becoming clearer, the mechanisms by which NMDAR gene expression is controlled are largely unknown. The molecular cloning of the NMDAR recently (Moriyoshi et al., 1991), however, has made studies of the regulation of gene expression morc fcasible.

The goldfish visual system serves as a readily accessible model for studies of gene expression in relation to synaptic changes in the adult animal. Following optic nerve crush, axons regrow from the retinal ganglion cell bodies to reinnervate the optic tectum, and the new retinotectal synapses, after an activity-dependent period of rearrangement and refinement, form a normal retinotopic map on the tectum (Grafstein, 1986). This system allows one to correlate changes in retinal ganglion cell gene expression with axonal outgrowth, synapse formation, and retinotectal map refinement. Within $2 \mathrm{~d}$ following optic nerve crush axonal sprouting is observed (Grafstein, 1986). At $2-4 \mathrm{~d}$ postcrush as axon elongation begins, $\alpha$-tubulin RNA levels in these cells begin to rise (Hieber et al., 1992, and Fig. 3). At 1-2 weeks postcrush, as the regenerating axons reach the tectum and synapse formation begins (Grafstein, 1986), nAChR RNA levels begin and $\alpha$ tubulin RN $\Lambda$ levels continue to rise and reach a maximum value (Hieber et al., 1992, and Fig. 3). Over the next 2-3 weeks the retinotectal synapses undergo a more precise mapping to correct retinotopic locations by an activity-induced process. Although injection of TTX into the eye during the first stage of regeneration does not prevent the axons from reaching the tectum, it prevents the precise retinotectal mapping of the latter stage from occurring (Meyer, 1983; Schmidt and Edwards, 1983). It is during this latter period, as $\alpha-3 \mathrm{nAChR}$ and $\alpha$-tubulin RNA levels are falling, that NMDAR RNA levels rise and peak in retinal ganglion cells (Fig. 3).

The main finding from this study is that during optic nerve regeneration, presynaptic NMDAR gene expression is induced by a mechanism that requires activation of postsynaptic NMDA receptors located in the optic tectum (Figs. 7, 8). This activation of postsynaptic NMDARs is most probably a result of glutamate release from the regenerated optic axon terminal, since glutamate is the primary neurotransmitter at the retinotectal synapse (Langdon and Freeman, 1986). This is consistent with our observation that regenerating optic axons must reach the optic tec- tum and be electrically active in order to induce presynaptic NMDAR gene expression (Figs. 4, 6).

Although we have not directly identified the cell types expressing the NMDAR gene in the retina's ganglion cell layer, it is likely that these cells are retinal ganglion cells. In contrast to many other species, goldfish contain very few displaced amacrine cells in the ganglion cell layer (Hitchcock and Easter, 1986; Bloomfield and Hitchcock, 1991). In addition, the target- and activity-dependent regulation that we have documented is most consistent with this gene being expressed in retinal ganglion cells residing in the ganglion cell layer.

The induction of NMDAR gene expression in retinal ganglion cells during the later stages of optic nerve regeneration was surprising. We initially chose to study this molecule because it was likely that NMDAR gene expression was regulated in the tectum during synapse stabilization. An increase in NMDAR 1 mRNA has been reported in rat superior colliculus during the postnatal period of visual map refinement, which involves synapse stabilization (Hofer et al., 1994). We assayed for tectal NMDAR RNA at various times during optic nerve regeneration by in situ hybridization and did not observe any dramatic changes in this RNA (unpublished observation). Since the probe that we used for these studies detects all known isoforms of NMDAR1, changes in individual isoforms could have been concealed by high levels of total NMDAR RNA. In contrast, using this same probe we did detect a significant and obvious change in expression in the presynaptic ganglion cell. Whether or not this regulation at the RNA level is also reflected in protein expression is not known. Antibodies that bind the NMDAR are being employed to address this issue.

The location of NMDARs affected by the antagonists injected into the intracranial cavity that regulate NMDAR RNA in regenerating retinal ganglion cells remains to be determined. While most experimental evidence from other studies points to a postsynaptic location for the NMDARs and functional postsynaptic NMDARs have been reported at retinotectal synapses of goldfish and amphibians (van Deusen and Meyer, 1990; Hickmott and Constantine-Paton, 1993), a presynaptic location at the retinotectal synapse cannot be ruled out. Recent reports indicate a presynaptic location for a glutamate receptor of the metabotropic type (Herrero et al., 1992) and for the GR33 protein, a glutamate binding protein with pharmacological properties characteristic of an NMDA receptor (Smirnova et al., 1993). Thus, while our conclusions concerning ganglion cell NMDAR RNA regulation are consistent with the involvement of a postsynaptic NMDAR in the tectum, the possible existence of presynaptic NMDARs on the regenerating axons cannot be entirely excluded.

The similarity between factors affecting NMDAR gene induction in regenerating retinal ganglion cells and those affecting retinotectal map refinement are striking. Temporally, these two events are taking place simultaneously. They both are activitydependent processes that require activation of postsynaptic NMDARs located in the tectum. It has been proposed that the tectal NMDARs function to recognize afferent coactivity, ultimately resulting in synapse stabilization (Constantine-Paton et al., 1990; Cline, 1991). Although we can identify common factors affecting synapse stabilization and presynaptic NMDAR gene induction, we do not know if presynaptic NMDARs participate in the process of synapse stabilization or are simply a consequence of it.

The NMDAR gene encodes multiple isoforms of the NMDAR 
(Sugihara et al., 1992; Hollmann et al., 1993). Our analysis of NMDAR gene expression did not distinguish between these isoforms, since our probes contained sequences common to all the NMDAR isoforms. The probe we isolated for studying NMDAR gene expression is a partial cDNA which contains $3^{\prime}$ untranslated sequences and encodes a portion of the NMDAR from the carboxy terminus through the cytoplasmic domain. In situ hybridization with either the full length cDNA or the $3^{\prime}$ untranslated region gave similar results. Since the NMDAR gene is expressed in both the ganglion and inner nuclear cell layers, we could not use RNase protection assays to distinguish the various isoforms expressed in the ganglion cell layer during optic nerve regeneration. The contribution from inner nuclear layer expression would make interpretation of the RNase protection data impossible. In order to identify the various NMDAR isoforms expressed in goldfish retinal ganglion cells, we are cloning the goldfish NMDAR gene, which will allow us to design isoform specific probes for in situ hybridization assays.

The identification of genes regulated by synaptic communication should provide sensitive probes for the molecular mechanisms by which this communication results in altered synaptic properties. NMDAR RNAs have been reported to be induced by activity-dependent mechanisms in the hippocampus during LTP (Smirnova et al., 1993) in depolarized cultured granule cells (Bessho et al., 1994) and during formation of retinocollicular maps (Hofer et al., 1994). In both the granule cells and the retinocollicular projection the increased expression of NMDAR RNA was reported to occur in the postsynaptic neuron. Prior to this study we were unaware of any reports of increased NMDAR RNA in presynaptic retinal ganglion cells during formation or regeneration of retinotectal synapses. However, in the hippocampus, there is a transient increase in presynaptic NMDAR RNA, GR33, as a result of induction of postsynaptic NMDARs during induction of LTP (Smirnova et al., 1993). Furthermore, all these systems appear to rely upon activation of postsynaptic NMDARs for initiating either a change in NMDAR RNA expression in the postsynaptic cell or generation of a signaling molecule that acts on the presynaptic neuron. For both cultured granule cells and LTP it appears that this activation is mediated via increases in intracellular calcium in the postsynaptic cell (Collingridge and Bliss, 1987; Brown et al., 1988; Bessho et al., 1994). In the case of stabilization of retinotectal synapses in the regenerating fish visual system, a calcium activatablc protcin kinase $\mathrm{C}$ activity has been implicated as playing a role in retinotopic sharpening (Schmidt, 1994).

Based on the similarities that we have uncovered between presynaptic NMDAR RNA induction during optic nerve regeneration, visual system development, and LTP (Constantine-Paton et al., 1990; Cline, 1991; Brown et al., 1988), we predict that unravelling the mechanisms mediating this regulation in fish will also identify mechanisms mediating these other events.

\section{References}

Bernhardt R (1989) Axonal pathfinding during the regeneration of the goldfish optic pathway. J Comp Neurol 284:119-134.

Bessho Y, Nawa H, Nakanishi S (1994) Selective up-regulation of an NMDA receptor subunit mRNA in cultured cerebellar granule cells by $\mathrm{K}^{+}$-induced depolarization and NMDA treatment. Neuron 12:8795.

Bloomfield SA, Hitchcock PF (1991) Dendritic arbors of large-field ganglion cells show scaled growth during expansion of the goldfish retina: a study of morphometric and electrotonic properties. J Neurosci 11:910-917.

Boos R, Muller F, Wassle, H (1990) Actions of excitatory amino acids on brisk ganglion cells in the cat retina. J Neurophysiol 64:13681379.

Brown TH, Chapman PFE, Kairiss W, Keenan CL (1988) Long-term synaptic potentiation. Science 242:724-728.

Cline HT (1991) Activity-dependent plasticity in the visual systems of frogs and fish. Trends Neurosci 14:104-111.

Coleman PA, Miller RF (1988) Do $N$-methyl-D-aspartate receptors mediate synaptic responses in the mudpuppy retina? J Neurosci 8:47284733.

Collingridge GL, Bliss TVP (1987) NMDA receptors-their role in long-term potentiation. Trends Neurosci 10:288-293.

Constantine-Paton M, Cline HT, Debski E (1990) Patterned activity, synaptic convergence and the NMDA receptor in developing visual pathways. Annu Rev Neurosci 13:129-154.

Davis RE (1990) Effect of optic nerve lesions and intraocular colchicine on cell proliferation in the germinal zone of the optic nerve and in the torus longitudinalis in the goldfish. Brain Res 512:46-53.

Davis RE, Schlumpf BE (1984) Visual recovery in goldfish following unilateral optic tectum ablation: evidence of competition between optic axons for tectal target. Behav Brain Res 13:287-291.

Davis RE, Schlumpf BE, Klinger PD (1985) Comparative neurotoxicity of tubulin-binding drugs: inhibition of goldfish optic nerve regeneration. Toxicol Appl Pharmacol 80:308-315.

Goldman D, Staple J (1989) Spatial and temporal expression of acetylcholine receptor RNAs in innervated and denervated rat soleus muscle. Neuron 3:219-228.

Gottesman J, Miller RF (1992) Pharmacological properties of $N$ - methyl-D-aspartate receptors on ganglion cells of an amphibian retina. J Neurophysiol 68:596-604.

Grafstein B (1986) The retina as a regenerating organ. In: The retina: a model for cell biology studies, Pt II (Adler R, Farber D, eds), pp 275-335. Orlando: Academic.

Herrero I, Miras-Portugal MT, Sanchez-Prieto J (1992) Positive feedback of glutamate exocytosis by metabotropic presynaptic receptor stimulation. Nature 360:163-166.

Hickmott PW, Constantine-Paton (1992) The contributions of NMDA, non-NMDA, and GABA receptors to postsynaptic responses in neurons of the optic tectum. J Neurosci 13:4339-4353.

Hieber V, Goldman D (1993) Cloning and analysis of nicotinic acetylcholine receptor gene expression in goldfish retina during optic nerve regeneration. Methods Neurosci 12:122-138.

Hieber V, Bouchey J, Agranoff BW, Goldman D (1990) Nucleotide and deduced amino acid sequence of the goldfish neural nicotinic acetylcholine receptor $\alpha-3$ subunit. Nucleic Acids Res 18:5293.

Hieber V, Agranoff BW, Goldman D (1992) Target-dependent regulation of retinal nicotinic acetylcholine reccptor and tubulin RNAs during optic nerve regeneration in goldfish. J Neurochem 58:1009-1015.

Hitchcock PF, Easter SS (1986) Retinal ganglion cells in goldfish: a qualitative classification into four morphological types and a quantitative study of the development of one of them. J Neurosci 6:10371050.

Hofer M, Prusky GT, Constantine-Paton M (1994) Regulation of NMDA receptor mRNA during visual map formation and after receptor blockade. J Neurochem 62:2300-2307.

Hollmann M, Boulter J, Maron C, Beasley L, Sullivan J, Pecht G, Heinemann S (1993) Zinc potentiates agonist-induced currents at certain splice variants of the NMDA receptor. Neuron 10:943-954.

Langdon RB, Freeman JA (1986) Antagonists of glutaminergic neurotransmission block retinotectal transmission in goldfish. Brain Res 398:169-174.

Massey SC, Miller RF (1990) $\mathrm{N}$-Methyl-D-aspartate receptors of ganglion cells in the rabbit retina. J Neurophysiol 63:16-30.

Meyer RL (1983) Tetrodotoxin inhibits the formation of refined retinotopography in goldfish. Dev Brain Res 6:293-298.

Moriyoshi K, Masu M, Ishii T, Shigemoto R, Mizuno N, Nakanishi S (1991) Molecular cloning and characterization of the rat NMDA receptor. Nature 354:31-37.

Northmore DPM (1987) Neural activity in the regenerating optic nerve of the goldfish. J Physiol (Lond) 391:299-312.

Scherer WJ, Udin SB (1989) N-Methyl-D-aspartate antagonists prevent interaction of binocular maps in Xenopus tectum. J Neurosci 9:38373843.

Schmidt IT (1990) Long-term potentiation and activity-dependent retinotopic sharpening in the regenerating retinotectal projection of 
goldfish: common sensitive period and sensitivity to NMDA blockers. J Neurosci 10:233-246.

Schmidt JT (1994) C-Kinase manipulations disrupt activity-driven retinotopic sharpening in regenerating goldfish retinotectal projection. J Neurobiol 25:555-570.

Schmidt JT, Edwards DL (1983) Activity sharpens the map during the regeneration of the retinotectal projection in goldfish. Brain Res 269 : $29-39$.

Springer AD, Agranoff BW (1977) Effect of temperature on role of goldfish optic regeneration: a radioautographic and behavioral study. Brain Res 128:405-415.

Stuermer CAO, Easter SS (1984) A comparison of the normal and regenerated retinotectal pathways of goldfish. J Comp Neurol 223: $57-76$.

Sugihara H, Moriyoshi K, Ishii T, Masu M, Nakanishi S (1992) Structures and properties of seven isoforms of the NMDA receptor generated by alternative splicing. Biochem Biophys Res Commun 185: 826-832.

van Deusen EB, Meyer RL (1990) Pharmacologic evidence for NMDA, APB and kainate/quisqualate retinotectal transmission in the isolated whole tectum of goldfish. Brain Res 536:86-96.

Yazejian B, Fain GL (1992) Excitatory amino acid receptors on isolated retinal ganglion cells from the goldfish. J Neurophysiol 67:94107. 